for the publication of articles and addresses by wellknown men of science, most of which have already appeared in previous publications such as Philosophy, Technology Review, Geographical Journal, Scientific Monthly, Report of the British Association, Science Progress, Nature, etc. This general appendix of well-chosen lectures, addresses and papers adds greatly to the value of these annual reports.

\section{The Pacific Science Congress}

THE Report for the year 1933-34 of the National Research Council of Japan contains the resolutions passed at the Fifth Pacific Science Congress held in Victoria, B.C. and Vancouver in June 1933. Steps were taken to secure more accurate information as to the depth, salinity and temperature of the ocean, the life conditions of halibut, salmon and whales in it and to prevent the discharge of oil from vessels on it. Plant diseases and parasites of the cereal crops and timber grown on the coasts and mountain ranges bordering them are to be studied more thoroughly, atmospheric circulation is to be investigated by pilot balloons, and the necessity of continuing magnetic, electric and oceanographic work by means of a new non-magnetic ship to replace the lost Carnegie was emphasised. Seismological informa. tion is to be spread by wireless as soon as it is arailable.

\section{Principles of Field Experimentation}

ThE Empire Cotton Growing Corporation has recently issued a volume of one hundred pages entitled "Prineiples and Practice of Field Experimentation", by J. Wishart and H. G. Sanders of the School of Agriculture, Cambridge. This is really the third edition of the volume, the first two, written by Engledow and Yule, having appeared in 1926 and 1930 respectively. Perhaps the most important improvements in method in the last ten years are the recognition of the usefulness of the factorial type of design, the confounding of main effects and high order interactions, the analysis of covariance and the fruits of many studies on sampling technique with cereals and root crops. Except for confounding, which is considered by the authors to be beyond the scope of the book, these topics are dealt with in this volume in a very readable manner. The section on practice contains much good advice on the planning and carrying-out of a field experiment, and is particularly welcome in that it answers many of the objections which have been raised by the so-called 'practical' man to modern methods of field experimentation.

\section{Statistical Abstract for the British Empire}

Probably the most generally useful statistical publications issued by H.M. Stationery Office are the various Statistical Abstracts, such as the Statistical Abstract for the United Kingdom, the Abstract of Labour Statistics and the Statistical Abstract for the British Empire. The sixty-fourth number of the last named has recently been published (H.M. Stationery Office, $3 s .6 d$.$) and contains a great wealth$ of statistical information relating to the exports and imports of the various Dominions, Colonies and Dependencies for each of the ten years 1925-34. It is, however, less complete than previous issues, which also included information relating to finance, production, prices, etc., but it is intended to publish the Abstract in complete form in aiternate years. Those who have frequent occasion to refer to statistical data will find this and the other Statistical Abstracts invaluable as a means of obtaining convenient summaries of official statistics drawn from very varied sources.

\section{Science Abstracts}

The issue of the index parts completes vols. 38 of Science Abstracts for 1935. The physics volume extends to 1,569 pages, 315 of which are occupied by a detailed subject index and key, and a name index. The electrical engineering volume has only 899 pages, 157 of which are index. Both are about the same size as the corresponding volumes last year. The average length of an abstract continues to be a little less than a quarter of a page, which experience seems to show is sufficient to allow an expert to give the gist of a paper, and allow a reader to keep abreast of research work in his own and kindred fields.

\section{Memorial to X-Ray Workers}

A STONE memorial to a hundred and sixty medical men, physicists, chemists, laboratory workers and nurses whose deaths were due to working with X-rays, was unveiled on April 4 at St. George's Hospital, Hamburg. The countries represented on the memorial are Germany, France, Great Britain, the United States, Italy, Hungary, Switzerland, Austria, Denmark, Czechoslovakia, Spain, Belgium, Finland, Russia and Holland. The British names inscribed are R. G. Blackall, C. R. C. Lister, Melville H. Walsham, C. Williams, E. E. Wilson, W. H. Fowler, J. S. Hall-Edwards, J. W. L. Spence, J. R. Riddell and W. I. Bruce Pirie.

\section{Announcements}

His MaJesty the King has been graciously pleased to grant his patronage to the Iron and Steel Institute. The Institute was similarly honoured by the late King George and by King Edward VII before him, both of whom had previously shown their interest in the Institute's activities by consenting to accept honorary membership. His Majesty King Edward VIII was also an honorary member until his accession to the throne.

THE Faraday Medal of the Institution of Electrical Engineers will be presented to Sir William Bragg at the ordinary meeting of the Institution to be held on Thursday, April 23, at 6 p.m. The presentation will precede the twenty-seventh Kelvin Lecture, which will be delivered by Dr. J. D. Cockcroft, on "The Transmutations of Matter by High-Energy Particles and Radiations". 
The following have been elected members of the Athenæum under the provisions of Rule II of the Club, which empowers the annual election by the Committee of a certain number of persons of distinguished eminence in science, literature, the arts, or for public service: Mr. Henry Balfour, curator of the Pitt-Rivers Museum, Oxford, and Dr. W. D. Ross, provost of Oriel College and University lecturer in philosophy, Oxford.

The Right Hon. the Eart of Athlone, Chancellor of the University of London, will open the new High Voltage Laboratory at Queen Mary College, London, on Wednesday, May 6, at 3.30 p.m.

Dr. J. T. IRving, lecturer in physiology at the School of Medicine, University of Leeds, has been appointed head of the Physiology Department of the Rowett Research Institute in succession to Dr. R. C. Garry, who has accepted the chair of physiology in the University of St. Andrews.

Dr. Antolne Béclère of Paris, formerly professor of clinical medicine in the University of Paris, the nestor of röntgenology, celebrated his eightieth birthday on March 17.

IT is announced in Science that Prof. Franz Boas, who has been professor of anthropology in Columbia University since 1899 , will retire on June 30 at the age of seventy-eight years.

Mr. C. C. Paterson will deliver the twenty-sixth annual May Lecture of the Institute of Metals on May 6 at 8 p.m., in the hall of the Institution of Mechanical Engineers, Storey's Gate, Westminster, S.W.1. The subject of the lecture will be: "The Escape of Electricity from Metals: its Practical Consequences".

ON the occasion of the twenty-fifth anniversary of the publication of the first edition of Ramon Turro's work on "The Origins of Knowledge", the Barcelona Society of Biology has offered an international prize of 2,000 pesetas for the best original and unpublished essay containing a critical study of Turro's scientific work. The essay, which may be in Catalan, Castilian, French, English, German or Italian, should be sent to the Secretary of the Society, Calle del Carmen 47, Barcelona, before May 25.

THE Proceedings and Transactions of the South London Entomological and Natural History Society for 1934-35 form a record of a successful year's activities. In addition to the accounts of the field and other meetings, together with annual reports, etc., the journal contains a number of articles written by various members of the Society. These contributions cover a wide range of subjects bearing upon insect life, and are of interest to the naturalist and student alike. The presidential address, by Mr. T. R. Eagles, dealing with the subjects of "Mendelism, Mimicry and Colour Conflict" is also included in the volume.
OwING to the present state of world affairs, the second International Congress of Mental Hygiene, which was to have been held in Paris next July, has been postponed until July 1937, when an international exhibition will be held in Paris. The exact date is not yet fixed, but it will probably be July 19 or 26 .

THE International Health Division of the Rockefeller Foundation wishes to obtain strains of virus from different outbreaks of influenza in order to compare their immunological properties in a study now in progress. Health authorities are requested to notify Dr. Johannes H. Bauer, Rockefeller Institute, York Avenue and 66th Street, New York.

TrE second International Congress of the World Fellowship of Faiths will be held in London on July 3-18. The subject of the Congress will be "World Fellowship through Religion". The international president is H.H. The Maharaja Gaekwar of Baroda, and the chairman of the British National Council is Sir Francis Younghusband. Further information can be obtained from the Organising Secretary, Mr. Arthur Jackman, 17 Bedford Square, London, W.C.l.

THE fourth International Congress for Experimental Cytology will be held in Copenhagen on August 10-15. The Congress will consider the following subjects; physical chemistry of the cell; histochemical problems and cell metabolism; experimental morphology; electrophysiology of the cell; experimental cell pathology and biology of irradiation. Further information can be obtained from the secretary of the Congress, Dr. Harald Okkels, Institute for Pathological Anatomy, 11 Frederik 5' V'ej, Copenhagen, Denmark.

The eighth International Medical Postgraduate Congress of the Tomarkin Foundation, New York, which has been organised under the auspices of the University of Athens in co-operation with the Grcek Ministry of Health, will be held at Athens under the presidency of Prof. Dustin, rector of the University of Brussels, on September 7-21. Lectures will be delivered 'on cardio-vascular diseases, surgery, tropical medicine and infectious diseases, dermatology, endocrinology and tuberculosis. During the Congress homage will be paid to the memory of Manson, Ross, Laveran, Golgi and Marchiafava, whose researches contributed to the solution of the problem of a successful campaign against malaria. A special steamer will leave Marseilles for Athens on September 2 or 3 . Further information can be obtained from the Tomarkin Foundation, 97 rue aux Laincs, Brussels.

Applicatrons are invited for the following appoint. ments, on or before the dates mentioned :

An assistant naturalist in the Fisheries Department of the Ministry of Agriculture and Fisheries-The Secretary, 10 Whitehall Place, S.W.I (April 27).

A chemical assistant in the Public Health Depart. ment of the London County Council-The Clerk to the Council, County Hall, Westminster Bridge, S.F.1 (May 4). 